\title{
KARAKTERISASI BAKTERI POTENSIAL PENDEGRADASI OLI BEKAS PADA TANAH BENGKEL DI KOTA PADANG
}

\author{
Yuni Ahda, Lel Fitri \\ Jurusan Biologi FMIPA Universitas Negeri Padang. \\ Jl. Prof. Dr. Hamka Air Tawar Barat Padang. \\ Email:ahdayuni@yahoo.com
}

\begin{abstract}
The research objective is to locate and determine the morphological and biochemical characteristics of the bacteria that could potentially degrade the used lubricant oil in the workshops in Padang. The research was conducted March to October 2016. The bacteria obtained from the workshop is cultured on selective media MSM and transferred to LB medium to obtain pure isolates. Morphological and biochemical characterization indicate three types of bacteria that live in workshop's soil contaminated used lubricant oil, namely Bacillus sp1, sp2 and Alcaligenes Bacillus sp.
\end{abstract}

Key words: biochemistry characterization, Bacillus, Alcaligenes

\section{PENDAHULUAN}

Kontaminasi tanah akibat pembuangan oli bekas secara sembarangan semakin meningkat di kota Padang. Salah satu penyebabnya adalah tidak tersedianya sarana pembuangan limbah oli bekas di bengkelbengkel rakyat. Bengkel-bengkel rakyat masih merupakan tempat yang banyak dimanfaatkan oleh para pengemudi mobil dan sepeda motor sebagai tempat mengganti oli kendaraan mereka. Bengkel-bengkel ini biasanya dimanfaatkan oleh pengendara yang memiliki kendaraan dengan tahun produksi di atas lima tahun dengan alasan biaya yang relatif murah.

Adanya bermacam-macam tipe mobil dan mesin mengakibatkan terjadinya peningkatan penggunaan oli. Tumpahan dari minyak pelumas bekas akan mengkontaminasi lingkungan dengan hidrokarbon (Husaini et al., 2008). Hidrokarbon khususnya polycyclic aromatic hydrocarbon (PAH) bersifat toksik, mutagenik dan karsinogenik (Bumpus et al., 1989; Clemente et al., 2001; Cerniglia and Sutherland, 2001). PAH sangat hidrofobik sehingga dapat tinggal dan meracuni tubuh manusia dan lingkungan. Pada manusia, kontaminasi dengan PAH dalam jangka waktu lama dan dalam jumlah besar dapat menyebabkan penyakit liver atau ginjal, kerusakan sumsum tulang dan meningkatkan resiko kanker (Mishra et al., 2001; Propst et al., 1999; Lloyd and Cackette, 2001). PAH dapat tersebar luas pada berbagai ekosistem (van Hamme et al., 2003).

Mengingat tingginya resiko penyakit yang dapat ditimbulkan oleh hidrokarbon dari minyak bekas, pemulihan lingkungan yang tercemar oleh hidrokarbon harus dilakukan. Salah satu usaha pemulihan lingkungan yang sangat banyak dilakukan saat ini adalah bioremediasi. Mikroorganisme adalah komponen utama dalam proses bioremediasi. Dari banyak jenis mikroorganisme, bakteri merupakan mikroorganisme potensial dalam proses bioremediasi. Nusyirwani dan Amolle (2012) berhasil mengisolasi tiga jenis bakteri dari perairan Dumai yang berpotensi dalam bioremediasi minyak bumi yaitu Providencia vermicola, Burkholderia cepacia dan Myroides 
Ahda, Y., \& Fitri, L. 2016. Karakterisasi Bakteri Potensial Pendegradasi Oli Bekas pada Tanah Bengkel di Kota Padang. Journal of Sainstek 8(2): 98-103

odoratimimus. Gofar (2012) juga berhasil mengkarakterisasi dua isolat bakteri yang berpotensi dalam bioremediasi minyak bumi yaitu Pseudomonas alcaligens dan Alcaligens facealis. Jauh sebelumnya Feliatra dalam Nusyirwani dan Amolle (2012) berhasil mengisolasi bakteri berpotensi pendegradasi minyak bumi dari perairan selat Malaka yaitu Acinetobacter sp, Arthrobacter sp., Micrococcus sp., Pseudomonas sp., Bacillus sp., Corinebacterium sp., dan Achromobacter sp. Sementara itu Arsanti dalam Nusyirwani dan Amolle (2012) juga menemukan bakteri potensial untuk bioremediasi minyak bumi seperti Azotobacter sp., Alcaligenes sp., Chromobacterium sp., Planococcus sp., dan Micrococcus sp. Penelitian ini bertujuan mengkarakterisasi bakteri yang diisolasi dari tanah tercemar oli bekas di bengkel kota Padang.

\section{METODE PENELITIAN}

\section{Koleksi Sampel Tanah}

Tanah dikoleksi dari bengkel yang tidak memiliki tempat pembuangan khusus. Tanah diambil dengan kedalaman $5-20 \mathrm{~cm}$ dari permukaan dengan spatula steril dan dimasukkan ke dalam Erlenmeyer. Tanah selanjutnya dibawa ke laboratorium untuk pembiakan bakteri.

\section{Pembuatan Media}

Media yang digunakan ialah media MSM (mineral salt medium), yang mengandung bahan-bahan berikut per liternya: $1,2 \mathrm{~g} \mathrm{NH} 4 \mathrm{Cl}$; 1,6 g K2HPO4; 0,4 g KH2PO4; 0,1 g NaCl, 1 g KNO3; 20 g MgSO4.7H2O; 10 g CaCl2.2H2O; $0,05 \mathrm{~g} \mathrm{FeCl} 3,1 \mathrm{~mL}$ larutan trace elemen (M'rassi, 2015). Larutan trace elemen mengandung bahan-bahan berikut per liternya: $50 \mathrm{mg} \mathrm{MnCl}$; $300 \mathrm{mg} \mathrm{H} 3 \mathrm{BO} 3,1,1 \mathrm{mg}$ FeSO4.7H2O; $190 \mathrm{mg} \mathrm{CoCl2.6H2O;} 2 \mathrm{mg}$ $\mathrm{CuCl} 2.2 \mathrm{H} 2 \mathrm{O} ; 24 \mathrm{mg} \mathrm{NiCl} 2.6 \mathrm{H} 2 \mathrm{O} ; 18 \mathrm{mg}$ $\mathrm{NaMoO} 4.2 \mathrm{H} 2 \mathrm{O} ; 42 \mathrm{mg} \mathrm{ZnCl} 2.7 \mathrm{H} 2 \mathrm{O}$ dan 1 $\mathrm{mL}$ larutan vitamin (Pfennig and Truper, 2006).

\section{Isolasi Bakteri Aerob Pendegradasi Hidrokarbon \\ Sebanyak 20 g sampel tanah} terkontaminasi minyak ditambahkan ke dalam $200 \mathrm{~mL}$ medium MSM. Suspensi selanjutnya diinkubasi pada suhu $27^{\circ} \mathrm{C}$, sambil dishaker dengan kecepatan 120 rpm selama 4 hari. Koloni bakteri yang tumbuh dengan warna berbeda, diambil satu ose dan ditanam kembali di cawan untuk dimurnikan menggunakan metode streak kuadran dengan teknik douplo. Koloni bakteri yang tumbuh terpisah pada medium cawan diamati kemudian diambil dengan ose steril dan ditumbuhkan di medium agar miring dalam tabung reaksi untuk disimpan sebagai stok kultur. Satu kultur murni merupakan satu isolat bakteri pendegradasi hidrokarbon. Setiap isolat bakteri diberi kode untuk penamaan awal.

\section{Identifikasi Isolat Bakteri Pendegradasi Hidrokarbon}

Koloni bakteri yang tumbuh setelah masa inkubasi dan sudah menjadi kultur murni diidentifikasi. Proses identifikasi dilakukan dengan mengidentifikasi karakter morfologi koloni sel dan karakter fisiologis. Identifikasi Isolat Bakteri Pendegradasi Hidrokarbon meliputi (a) a. Pengamatan morfologi koloni, meliputi bentuk koloni, warna koloni, tepi koloni, dan elevasi koloni; (b) Pengamatan mikroskopis, meliputi bentuk sel bakteri, pewarnaan gram dan keberadaan sporanya dan (c) Pengamatan biokimia, meliputi antara lain uji TSIA, Gas, H2S, Catalase, Oksidase, Mortilitas, Indol, Urea, Citrat, Laktosa, Glukosa, Sukrosa, Mannitol, MR, VP, OF, dll.

\section{HASIL DAN PEMBAHASAN}

\section{Hasil Penelitian \\ Karakterisasi Morfologi Koloni}

Berdasarkan sumber tanah (di bengkel dan di luar bengkel) didapatkan delapan isolat yang tumbuh pada medium seleksi MSM. Namun dari hasil perbandingan karakteristik morfologi didapat empat isolat dengan morfologi yang berbeda (Tabel 1). 
Ahda, Y., \& Fitri, L. 2016. Karakterisasi Bakteri Potensial Pendegradasi Oli Bekas pada Tanah Bengkel di Kota Padang. Journal of Sainstek 8(2): 98-103

Tabel 1. Karakteristik Morfologi Koloni Bakteri dari Tanah Tercemar Oli Bekas di Satu Bengkel di kota Padang

\begin{tabular}{clccc}
\hline Sampel & \multicolumn{1}{c}{ Bentuk } & Tepian & Elevasi & Warna \\
\hline D1 & tidak beraturan dan menyebar & licin & datar & Putih \\
D2 & bundar dengan tepian karang & berombak & berbukit-bukit & Putih \\
D3 & bundar dengan tepian karang & tak beraturan & datar & Putih \\
D4 & bundar & licin & berbukit-bukit & kuning \\
\hline
\end{tabular}

Tabel 2. Hasil Uji Biokimia Isolat bakteri dari Tanah Tercemar Oli Bekas di Satu Bengkel di Kota Padang

\begin{tabular}{|c|c|c|c|c|}
\hline \multirow{2}{*}{ No. } & \multirow{2}{*}{ Perlakuan } & \multicolumn{3}{|c|}{ Koloni yang Diproses } \\
\hline & & D1 dan D3 & D2 & D4 \\
\hline 1. & Gram (morfologi, spora) & + basil, spora & + basil, spora & + basil, spora \\
\hline 2. & Aerob/Anaerob & aerob & aerob & Aerob \\
\hline 3. & TSIA & $K / K$ & $M / K$ & $\mathrm{M} / \mathrm{K}$ \\
\hline 4. & Gas & - & - & - \\
\hline 5. & $\mathrm{H}_{2} \mathrm{~S}$ & - & - & - \\
\hline 6. & Catalase & + & + & + \\
\hline 7. & Oksidase & & & + \\
\hline 8 & Mortilitas & & & + \\
\hline 9. & Indol & & & - \\
\hline 10. & Urea & & & - \\
\hline 11. & Citrat & & & - \\
\hline 12 & Laktosa & & & - \\
\hline 13. & Glukosa & & & - \\
\hline 15 & Sukrosa & & & - \\
\hline 16. & Mannitol & & & - \\
\hline 17. & MR & & & - \\
\hline 18. & VP & & & - \\
\hline 19. & $\mathrm{CF}$ & & & + \\
\hline 20 . & $\mathrm{KCN}$ & & & + \\
\hline 21 & Arginin & & & - \\
\hline 22. & Lisin & & & - \\
\hline 23. & Omithin & & & - \\
\hline 24. & Phenylalanin & & & - \\
\hline 25 . & Aesculin & & & - \\
\hline 26. & Arabinose & & & - \\
\hline 27. & Raffinose & & & - \\
\hline 28. & Sorbitol & & & - \\
\hline 29. & Trehalase & & & - \\
\hline 30. & Xylose & & & - \\
\hline 31. & Dulcitol & & & - \\
\hline 32. & Malonat broth & & & - \\
\hline 33. & Nitrat & + & + & - \\
\hline 34. & Gelatin & + & + & - \\
\hline
\end{tabular}

Dari Tabel 1 terlihat empat isolat dengan karakter morfologi berbeda. Namun hasil karakterisasi morfologi belum bisa memberi informasi tentang genus dari isolat yang didapat. Oleh karena itu perlu dilanjutkan dengan karakterisasi biokimia. 


\section{Karakterisasi Biokimia}

Hasil karakterisasi biokimia dituliskan di Tabel 2. Berdasarkan data pada Tabel 2, disimpulkan ada tiga spesies bakteri yang didapat dari tanah tercemar oli bekas pada bengkel di kota Padang, yaitu Bacillus spl (isolat D1 dan D3), Bacillus sp2 (isolat D2), dan Alcaligenes sp (isolat D4). Isolat bakteri D1 sama dengan isolat bakteri D3.

\section{Pembahasan}

Hasil karakterisasi biokimia menemukan tiga spesies bakteri yang mampu hidup di tanah tercemar oli bekas. Tiga spesies bakteri yang didapat berpotensi dalam mendegradasi oli bekas sebagai sumber karbon dan hidrogen bagi kehidupan bakteri. Oli adalah salah satu produk hasil pengolahan minyak bumi yang kaya akan hidrokarbon alifatik dan aromatik. Ketiga jenis bakteri yang didapat sejalan dengan hasil temuan Feliatra; Arsanti dalam Nusyirwani dan Amolle (2012) yang mengisolasi bakteri hidrokarbonoklastik dari perairan Selat Malaka dan sedimen muara Sungai Dumai. Zam (2006) juga menemukan beberapa spesies bakteri yang mampu mendegradasi minyak bumi dari sungai Pakning Riau seperti Acinetobacter baumanni, Alcaligenes eutropus, Bacillus sp1., Methylcoccus capsulatus, Bacillus sp2, Morococcus sp., Pseudomonas diminuta, Xanthomonas albilineans, Bacillus aereus, dan Flavobacterium branchiophiia. Sementara itu Zam (2006) juga berhasil mengisolasi bakteri hidrokarbonoklastik dari minyak bumi Sumur Bangko Rokan Hilir dan menemukan beberapa spesies bakteri seperti Bacillus polymyxa, Bacillus licheniformis, Bacillus sp1., Pseudomonas aeruginosa, Bacillus sp2., Bacillus stearothermophillus, Bacillus brevis, dan Bacillus coagulans. Berdasarkan hasil penelitian Zam (2006) diketahui banyak jenis Bacillus yang mampu mendegradasi minyak bumi. Bacillus sp1. dan Bacillus sp2. yang ditemukan dalam penelitian ini mungkin sama dengan hasil temuan Zam (2006) atau mungkin juga bisa berbeda. Menurut Pikoli et al. (2000) bakteri memiliki kemampuan untuk menggunakan komponen yang berbeda dalam crude oil.
Bacillus adalah genus bakteri gram positif berbentuk batang dan anggota dari filum Firmicutes. Spesies Bacillus dapat aerob obligat, atau anaerob fakultatif. Mereka akan teruji positif untuk enzim katalase ketika ada oksigen digunakan atau hadir (Turnbull, 1996). Ada di mana-mana di alam, Bacillus meliputi spesies yang hidup bebas dan patogen parasitik. Dalam kondisi lingkungan stres, bakteri dapat menghasilkan endospora oval yang bukan 'spora' sejati, tapi di mana bakteri dapat mengurangi diri mereka sendiri dan tetap dalam keadaan tidak aktif untuk jangka waktu yang lama. Karakteristik ini awalnya mendefinisikan genus, tetapi tidak semua spesies tersebut terkait erat, dan banyak yang telah dipindahkan ke genera lain dari Firmicutes (Madigan and Martinko, 2005).

Bacillus licheniformis adalah bakteri yang banyak ditemukan di tanah. $B$. licheniformis bersifat gram-positive dan merupakan bakteri mesofilik dengan pertumbuhan optimal pada kisaran suhu 50C, namun dapat tumbuh pada suhu di atas pertumbuhan optimalnya. Suhu optimal untuk sekresi enzim adalah 37C. Bila kondisi lingkungan kurang baik, B. licheniformis hadir dalam bentuk spora, namun akan kembali ke fase vegetatif bila kondisi lingkungan sudah baik (Schallmey et al., 2004).

Brevibacillus brevis dulu dikenal sebagai Bacillus brevis. B. brevis adalah bakteri gram positif dan bersifat aerob. Dalam bentuk spora sering dijumpai di tanah, udara, air dan bahanbahan yang mengalami pelapukan. B. brevis tumbuh optimal pada suhu $35-55 \mathrm{C}$, membentuk spora motil dan memiliki aktivitas katalase positif, amylase negatif, kasein negatif, gelatinase positif dan indole negatif (Shida et al., 1996).

Alcaligenes eutrophus atau Ralstonia eutrophus adalah spesies bakteri yang dapat memproduksi poli(3-hydroksibutirat) (PHB), bahan pembuat plastik yang mudah diurai (biodebradable plastic) (Mergeay, et al., 1985). Bakteri ini memiliki beberapa karakteristik, yaitu gram-negatif, berbentuk basil, tidak membentuk spora, tumbuh pada suhu optimal $30{ }^{\circ} \mathrm{C}$, aerobik obligat (memerlukan $\mathrm{O}_{2}$ untuk hidup), fakultatif kemolitotrof, dan dapat 
Ahda, Y., \& Fitri, L. 2016. Karakterisasi Bakteri Potensial Pendegradasi Oli Bekas pada Tanah Bengkel di Kota Padang. Journal of Sainstek 8(2): 98-103

menghasilkan energi dengan mengoksidasi hidrogen menjadi air. A. eutrophus sering ditemukan di tanah atau lapisan sedimen yang mengandung logam berat dalam konsentrasi tinggi. A. eutrophus dapat mensintesis PHB melalui jalur metabolisme Asetil-KoA dengan melibatkan tiga enzim, yaitu 3-ketotiolase, asetoasetil-KoA reduktase, dan PHA (polihidroksialkanoat) sintase (Mergeay, et al., 1985). Salah satu kelebihan lain dari bakteri ini adalah dapat menggunakan beberapa senyawa aromatik sebagai satu-satunya sumber karbon dan energi untuk hidup (People et al., 1989).

\section{KESIMPULAN}

Bakteri yang diisolasi dari tanah tercemar oli bekas dari satu bengkel di kota Padang terkarakterisasi sebagai Bacillus sp1, Bacillus $s p 2$ dan Alcaligenes sp. Bakteri ini berpotensi sebagai bakteri pendegradasi oli bekas sehingga dapat digunakan dalam kegiatan bioremediasi. Pada penelitian ini belum terungkap secara jelas spesies bakteri yang didapat karena keterbatasan analisis. Untuk itu perlu dilanjutkan dengan analisis molekuler dengan melakukan sekuensing dan alignment gen 16sRNA.

\section{UCAPAN TERIMA KASIH}

Terima kasih disampaikan kepada Kemenristekdikti dan Rektor Universitas Negeri Padang yang telah mendanai penelitian ini melalui skema penelitian Hibah Bersaing Desentralisasi tahun anggaran 2016. Terima kasih juga disampaikan kepada Kurnia Sari yang telah membantu dalam kegiatan laboratorium selama penelitian berlangsung.

\section{DAFTAR KEPUSTAKAAN}

Bumpus JA. 1989. Biodegradation of polycyclic aromatic hydrocarbon by Phanerochaete chrysosporium. Applied and Environmental Microbiology; 55(1):154-158
Cerniglia CE and Sutherland JB. 2001. Bioremediation of polycyclic aromatic hydrocarbon by ligninolytic and nonligninolytic fungi. In Fungi in Bioremediation. Gadd GM. Ed. 136-187. Cambridge University Press, Cambridge, UK.

Clemente AR, Anazawa TA, Durrant LR. 2001. Biodegradation of polycyclic aromatic hydrocarbon by soil fungi. Brazilian Journal of Microbiology; 32(4):255-261.

Gofar N. 2012. Aplikasi Isolate Bakteri Hidrokarbonoklastik Asal Rizosfer Mangrove pada Tanah Tercemar Minyak Bumi. Jurnal Lahan Suboptimal; 1(2):123-129.

Husaini A, Roslan HA, Hii KSY, Ang CH. 2008. Biodegradation of aliphatic hydrocarbon by indigenous fungi isolated from used motor oil contaminated sites. World Journal of Microbiology and Biotechnology; 24(12):2789-2797.

Llyod AC. and Cackette TA. 2001. Diesel engines: environmental impact and control. Journal of the Air and Waste Management Association; 51(6):809-847.

Mishra S., Jyot J., Kuhad RC., Lal B. 2001. Evaluation of inoculums addition to stimulate in situ bioremediation of oilysludge-contaminated soil. Applied and Environmental Microbiology; 67(4):1675-1681.

Nusyirwani dan Amolle KC. 2007. Isolasi dan Karakterisasi Bakteri Hidrokarbonoklastik dari Perairan Dumai dengan Sekuens 16S rDNA. Ilmu Kelautan; 12(1):12-17.

Propst TL, Lochmiller RL, Qualls CW, Mcbee K. 1999. In situ (mesocosm) assessment of immunotoxicity risks to small mammals inhabiting petrochemical waste sites. Chemosphere; 38(5):1049-1067.

Schallmey, Marcus, Singh, Ajay, Ward, Owen P. 2004. Developments in The Use of Bacillus species for Industrial Production. Canadian Journal of Microbiology, 50(1):1-17. 
Ahda, Y., \& Fitri, L. 2016. Karakterisasi Bakteri Potensial Pendegradasi Oli Bekas pada Tanah Bengkel di Kota Padang. Journal of Sainstek 8(2): 98-103

Shida O, Takagi H, Kadowaki K, Komagata K. Zam $\quad$ SI. 2006. Bioremediasi Limbah 1996. Proposal for Two New Genera, Brevibacillus gen.nov and Anouriniba bacillus gen.nov. International Journal of Systematic Bacteriology, 46(4):939-946.

Van Hamme JD, Singh A, Ward OP. 2003. Recent advances in petroleum microbiology. Microbiology and Molecular Biology Reviews; 67(4):503549.

Pengilangan Minyak Bumi Pertamina UP II Sungai Pakning dengan Menggunakan Bakteri Indigen. Program Studi Bioteknologi, ITB. Bandung. Ganesha Digital Library. 